\title{
STUDIES OF THE FLASH FIRE POTENTIAL OF AIRCRAFT CABIN INTERIOR MATERIALS
}

\author{
Michael J. Manka \\ Henry Pierce \\ Clayton Huggett
}

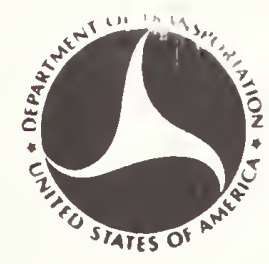

DECEMBER 1977

\section{FINAL REPORT}

Document is available to the public through the

National Technical Information Service

Springfield, Virginia 22151

Prepared for

\section{U. S. DEPARTMENT OF TRANSPORTATION FEDERAL AVIATION ADMINISTRATION}

Systems Research \& Development Service

Washington, D.C. 20590 


\section{NOTICE}

The United States Government does not endorse products or manufacturers. Trade or manufacturers' names appear herein solely because they are considered essential to the object of the report.

\section{NOT ICE}

This document is disseminated under the sponsorship of the Department of Transportation in the interest of information exchange. The United States Government assumes no liability for its contents or use thereof. 


\begin{tabular}{l|l}
\hline 1. Report No. & 2. Government Accession No. \\
FAA-RD-77-47 &
\end{tabular}

4. Title ond Subtitle

Studies of the Flash Fire Potential of

Aircraft Cabin Interior Materials

7. Author's)

Michael J. Manka, Henry Pierce, Clayton Huggett

9. Performing Orgonizotion Nome ond Address

National Bureau of Standards

Washington, D.C. 20234

12. Sponsoring Agency Nome ond Address

Department of Transportation

Federal Aviation Administration

Systems Research and Development Service

Washington, D.C. -20590

15. Supplementory Notes

This work was supported in part by the National Aviation Facilities Experimental Center (NAFEC) Atlantic City, New Jersey 08405. Mr. Constantine P. Sarkos was the NAFEC project manager.

16. Abstroct

This is the third in a series of reports describing work carried out under the joint sponsorship of the National Bureau of Standards (NBS) and the Federal Aviation Administration (FAA) to develop a method of assessing the flash fire potential of materlals found in aircraft cabin interiors.

The flash fire cell described in the previous report was modified further and used to evaluate the flash fire potential of a series of 24 typical aircraft cabin interior materials. Flash fires were observed in the apparatus at fuel loadings as low as $0.23 \mathrm{gL}^{-1}$.

A minimum energy principle was proposed to characterize the flash fire behavior of the complex mixture of fuels derived from the pyrolysis of organic materials. This principle states that a flash fire is possible when the potential combustion energy content of the pyrolyzate-air mixture exceeds approximately $425 \mathrm{cal}^{-1}$.

A variety of experiments was performed to provide support for the minimum energy principle. The results were in general agreement with predictions, but the accuracy of the measurements was not good enough to permit detailed conclusions.

Oxidative pyrolysis plays a significant role in the formation of the fuel-air mixture in the flash fire cell. Particulates contribute to the creation of flash fire conditions, but they present a difficult measurement problem.

17. Key Words

Aircraft Materials

Combustion Products

Flash Fire

18. Distribution Stotement

Document is available to the public through the National Technical Information Service, Springfield, Virginia 22151
19. Security Clossif. (of this report)

Unclassified
20. Security Clossif. (of this poge)

Unclassified

\begin{tabular}{|l|l|}
$\begin{array}{l}\text { 21. No. of Poges } \\
37\end{array}$ & 22. Price \\
\hline
\end{tabular}





\section{PREFACE}

This is the third in a series of reports describing work carried out under the joint sponsorship of the National Bureau of Standards (NBS) and the Federal Aviation Administration (FAA) to develop a method of assessing the flash fire potential of materials found in aircraft cabin interiors.

This work was supported in part by the FAA's National Aviation Facilities Experimental Center (NAFEC), Atlantic City, New Jersey 08405 under FAA/NBS Agreement No. FA67-NF-AP-21. Mr. Constantine P. Sarkos was the NAFEC project manager. 
INTRODUCTION . . . . . . . . . . . . . . . . . . . 1

Purpose . . . . . . . . . . . . . . . . . . 1

Background . . . . . . . . . . . . . . . . . 1

EVALUATION OF THE FLASH FIRE POTENTIAL OF AIRCRAFT CABIN

INTERIOR MATERIALS . . . . . . . . . . . . . . . . . . 2

Materials . . . . . . . . . . . . . . . . . 2

Flash Fire Cell . . . . . . . . . . . . . . . . 2

Experimental Procedure . . . . . . . . . . . . . . . 2

Test Results--Flash Fire Potential . . . . . . . . . . 3

INVESTIGATION OF CONDITIONS WHICH CAN LEAD TO A FLASH FIRE • . • 4

The Minimum Energy Principle . . . . . . . . . . . . 5

Experimental Materials . . . . . . . . . . . . . . 7

Methods of Experimental Measurement of the Energy Content

of Pyrolysis Gases . . . . . . . . . . . . . . . 7

Measurement of Energy Content of Pyrolysis Gases in the

Flash Fire Cell . . . . . . . . . . . . . . . 8

Probe Pyrolysis Experiments . . . . . . . . . . . 9

Sample 8 . . . . . . . . . . . . . . . . . . 9

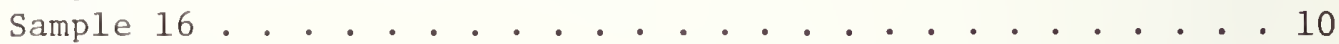

Sample 38 . . . . . . . . . . . . . . . . . 10

Sample 42 . . . . . . . . . . . . . . . . . . . 10

Summary of Energy Content Measurements . . . . . . . . . 10

Gas Analysis Experiments . . . . . . . . . . . . . 11

SUMMARY AND CONCLUSIONS . . . . . . . . . . . . . . . 12

REFERENCES . . . . . . . . . . . . . . . . . . 13 


\section{LIST OF FIGURES}

Figure

Page

1 Modified Flash Fire Cell . . . . . . . . . . . 24

2 Typical Experimental Run where Sample Pyrolyzates

Produce a Flash Fire . . . . . . . . . . 25

3 Pyrogram of Sample 8 in Nitrogen . . . . . . . . . 26

4 Pyrogram of Sample 16 in Nitrogen . . . . . . . . . 27

5 Pyrogram of Sample 38 in Nitrogen . . . . . . . . . 28

6 Pyrogram of Sample 42 in Nitrogen . . . . . . . . . 29

LIST OF TABLES

Table

Page

1 Materials Evaluated in Flash Fire Cell . . . . . . . . 14

2 Flash Fire Test Results . . . . . . . . . . . 16

3 Ranking of FAA Samples which Flashed . . . . . . . . . 17

$4 \quad$ FAA Samples which Failed to Produce a Flash under the Test Conditions . . . . . . . . . . . 17

5 Results of Composite Samples . . . . . . . . . 18

6 Lean Limit Mixture Heats of Combustion for Upward Flame Propagation of Organic Fuels . . . . . . 19

7 Properties of Polyurethane Foam Samples . . . . . . . 19

8 Results of Flash Fire Experiments for Samples

$8,16,38 \& 42$. . . . . . . . . . . . 20

9 Results of Energy Measurements of Flash Fire Experiments for Samples 8, 16, 38 and 42 . . . . . . 21

10 Energy Measurements from Flash Fire Experiments . . . . 22

11 Comparison of Energy per Unit Volume at the Minimum Mass Limit as Determined by Various Methods . . . . 22

12 Gas Analysis Results from Flash Fire Cell Experiments . . 23 


\section{INTRODUCTION}

\section{PURPOSE}

The purpose of this project was to develop a method of evaluating the flash-fire potential of aircraft cabin materials, to evaluate selected materials and conduct additional studies to gain a more complete understanding of the phenomenon of flash fire.

\section{BACKGROUND}

Accidents have occurred in which an impact-survivable crash landing of a passenger aircraft was followed by a rapidly propagating fire in the aircraft cabin, causing extensive casualties among the passengers and crew before evacuation or rescue could be effected. While such events are fortunately rare, their catastrophic nature has focused attention on developing an understanding of the mechanism of these cabin "flash fires" and developing means for their control.

Previous NBS reports, dealing with flash fire studies, described exploratory experiments in which a flash fire cell was constructed and used to make preliminary comparisons of various polymers and to assess the usefulness of the apparatus used for measuring the flash fire potential of materials (reference [1]). An analysis of the pyrolysis gases and smoke evolving from thermal decomposition of polyurethane foam was also performed. The results indicated that smoke was playing a significant role in producing a flash fire since a flash did not occur when the smoke was filtered out. A later study [2] refined the technique of using the flash fire cell to assess the flash fire potential of materials. In that work several variables, including cell orientation and oven temperature, were studied and an experimental procedure was established. The important parameters in assessing the flash fire potential of polyurethane foam were found to be, (1) the minimum mass of sample per unit volume needed to produce a flash fire, and (2) the minimum temperature the sample needed to reach in order to produce a combustible pyrolyzate/air mixture. This minimum temperature was found to be about $380^{\circ} \mathrm{C}$ for polyurethane foam. The minimum mass depended on the chemical structure of the sample and its decomposition products.

In the present work the flash fire cell was further developed and used to evaluate the flash fire potential of a series of aircraft interior materials. Based on a minimum gas phase energy hypothesis, experiments were carried out to investigate the conditions which could produce flash fires. 


\section{MATERIALS}

Twenty-four typical materials found in aircraft cabin interiors were supplied by NAFEC for evaluation. A listing of these materials, their description and usage are presented in table 1.

\section{FLASH FIRE CELL}

The flash fire cell described previously [2] was modified to provide greater flexibility in operation. A sketch of the present cell is shown in figure 1. The body of the cell was constructed from a length of 5 centimeter $(\mathrm{cm})$ inner diameter I.D. pyrex glass pipe. The volume of the cell was increased to 1.69 liters (L). A magnetically driven stirrer was added to improve mixing of the pyrolyzate with air. Thermocouples were inserted through the sampling septums to detect the passage of a combustion wave and allow an estimate of flame speed. These septums were also used to withdraw gas samples for analysis by means of a gas tight syringe. The polarographic type oxygen probe, retained and mounted in a plastic plate, was held in place at the bottom of the cell by a set of springs. This spring loaded plate provided a pressure release mechanism in the event of a pressure buildup during pyrolysis or a flash fire. The entire cell was designed for easy disassembly and cleaning between experiments.

The manual ignition control was replaced by an electronic system which provided precise and reproducible control of the spark duration and the interval between sparks. The igniter was constructed from platinum electrodes with a 6 millimeter (mm) spark gap. A 10 thousand volt (kV) spark was used for ignition of the pyrolyzate/air mixture. This source was sufficiently strong to ensure ignition of any combustible mixture.

\section{EXPERIMENTAL PROCEDURE}

A weighed sample of the material to be evaluated was placed in the cell as shown in figure 1 . The furnace, which had been preheated and thermostated at a preselected temperature, usually $500{ }^{\circ} \mathrm{C}$, was placed over the side arm containing the sample to initiate pyrolysis. Preliminary experiments had shown that a temperature of $500{ }^{\circ} \mathrm{C}$ was sufficient to bring about complete pyrolysis of most organic materials.

Sample temperature, as measured by a chromel-alumel thermocouple, and oxygen concentration were recorded continuously during the experiment. The sample experienced a heating rate of about $200-250{ }^{\circ} \mathrm{C}$ per minute, similar in magnitude to that which would be encountered in a fire exposure. 
With the onset of pyrolysis the ignition source was activated to give a spark of one second duration at regular intervals. The sparking was continued until a flash occurred or pyrolysis of the sample was complete and it appeared that no flash would occur. A record of a typical experiment in which a flash occurs is shown in figure 2. The occurrence of a flash fire could be detected by a visibly luminous flash, a sharp deflection in the oxygen concentration record, or a sudden increase in temperature indicated by the thermocouples in the cell.

Initially a sample weighing about 1 gram $(\mathrm{g})$ was tested by the procedure outlined above. If no flash occurred, the sample size was doubled for the next trial. If a flash did occur, the sample size was suitably reduced for the next trial. In this way the minimum sample mass which would produce a flash in the apparatus was established with reasonable accuracy in the course of a few trials.

Because of the limited quantities available, the minimum mass could not be established for some samples. In these cases the largest sample tested was reported. Some materials were considered to have a low flash fire potential so they were not studied further. Due to the limited volume of the sample holder, some of the low density composite panel materials could not be tested in their original configuration. These materials were separated into their principal components and each component was tested separately. The minimum mass of the composite material was then calculated by the formula

$$
\min \cdot \operatorname{mass}=\left[\sum_{i} \frac{x_{i}}{m_{i}}\right]^{-1}
$$

where $m_{i}$ is the minimum mass of component $i$ and $x_{i}$ is the weight fraction of component $i$ in the composite.

TEST RESULTS--FLASH FIRE POTENTIAL

Results obtained with the 24 cabin interior materials tested by the procedure described above are summarized in table 2 . In cases where a flash was obtained, the minimum mass per unit volume is given. Where the sample failed to produce a flash, the largest sample tested (g/L) is given and the symbol ( $>$ ) indicates that the minimum mass will be greater than the quantity listed. For the most part, failure to establish a minimum mass was due to a lack of sufficient sample, but in the case of the fiberglass samples (27, 66 and 115A) the sample size was limited by the size of the sample holder. 
The maximum temperature reached by the sample and the oxygen concentration achieved at the time of flash or the minimum oxygen concentration in the case of samples which did not flash are also listed in table 2 . Some variation was observed from test to test, therefore, the range of sample temperature and oxygen concentration are presented in the table.

It should be noted that about half of the samples did not produce any flash even for relatively large sample sizes. This is not surprising since these materials are composed of relatively inert or thermally stable components, such as fiberglass, or flame resistant polymers, such as Nomex. Both the polyvinyl chloride (PVC) foam (86) and polycarbonate (32 and 111) samples did yield flashable mixtures. The two flameretardant urethane foam samples (143A and 143C) yielded quite different minimum mass results. Sample $143 \mathrm{C}$ is considerably more resistant to flashing whereas in sample $143 \mathrm{~A}$ the flame retardant appears to be relatively ineffective in preventing a flash.

The samples which produced a flash.can be ranked according to the minimum mass criterion as shown in table 3. The poly (phenylene oxide) and polyether polyurethane samples (117 and 143A) were the most easily flashed. Samples which failed to give a flash under the test conditions are listed in table 4 in the order of increased sample size tested. This does not provide a ranking since there is no way of determining from the present data that these samples approached the minimum mass. At best, it can only be said that their flash fire potential is considerably lower than the first 10 materials listed in table 3. Additional testing with larger samples would provide further differentiation.

Some composite samples were directed into their different components and each individually tested in the flash fire cell. These included samples 1, 2, 14, 37, 50,61, and 67. The results of these tests are shown in table 5. The weight fraction of each component is also given. The Nomex core and some fiberglass facings were not tested as they were usually destroyed during the separation process. It was expected that these materials would not contribute significantly to reducing the minimum mass and they were therefore excluded from the calculation of the total minimum mass.

\section{INVESTIGATION OF CONDITIONS WHICH CAN LEAD TO A FLASH FIRE}

A flash fire may be described as the rapid propagation of a combustion wave through a gaseous fuel-oxidizer mixture. In the present context the fuel consists of the partially oxidized pyrolysis products from the cabin interior materials. The oxidizer is oxygen from the air, either that present in the cabin originally or an additional supply introduced through cabin openings. The fuel may be generated by a slow smoldering combustion where the products mix with the cabin air to form a combustible mixture but the temperature is too low to cause ignition. An independent ignition source may then trigger the flash fire. Alternatively, the fuel 
may be generated by open flaming under conditions of limited oxygen availability (excess pyrolyzate [3]). In this case a fuel rich, oxygen deficient, mixture will be generated which can burst into flame when external oxygen is admitted.

The propagation of a flame through a fuel-air mixture has been studied in considerable detail [4]. It is found that a well defined minimum fuel concentration, called the lower or lean limit (LL), must be exceeded for the flame to propagate. As the fuel concentration is increased further the flame speed first increases, passes through a maximum, and then decreases until the flame is extinguished at a concentration called the upper or rich limit. Above this upper limit, the system is fuel rich and the oxygen concentration is too low to support combustion. For our present purpose of defining conditions which can lead to a flash fire we will be concerned only with the lower flammability limit since a fuel rich mixture can always pass into the flammable region by the addition of air. Then for a flash fire to occur, we can say that the fuel concentration must exceed the lower flammability limit and materials which produce large quantities of gaseous fuels during pyrolysis have a high flash fire potential.

The lower flammability limit varies only slightly with temperature and pressure within the normal range of atmospheric conditions. Lower limits have been measured for a variety of fuels [4]. The lower limit for a mixture of fuels can be calculated from the individual values by Le Chatelier's law.

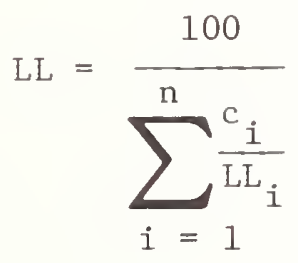

where $c_{i}$ and $L_{i}$ are the percentage composition and lower limit, respectively, of the ith combustible in the mixture. If we know the quantities and species of fuel gases produced by the pyrolysis of a material we can calculate the lower limit and the quantity of material which will produce flash fire conditions in a given volume of air. The mixtures of products that are produced by the pyrolysis of most organic materials are, however, so complex that this procedure is quite difficult and therefore of little practical value. Fortunately, a simplifying generalization makes this complex analytical task unnecessary.

THE MINIMUM ENERGY PRINCIPLE

Lower flammability limits have been measured for a variety of organic vapors [5]. The percentage of fuel by volume in the lower limit mixture varies widely, but the product of lower limit fuel concentration per 
unit volume and heat of combustion is nearly constant for most organic fuels (table 6) [6]. A few highly unsaturated compounds and non-organic species deviate significantly from this rule, but these are unlikely to be important in our application. Then at the lower flammability limit we have

$$
\begin{aligned}
{ }^{(x)}{ }_{\mathrm{LL}} \cdot \Delta_{\mathrm{C}}= & 10.4 \pm 0.8 \mathrm{~K} \mathrm{cal} \mathrm{mole} \mathrm{H}^{-1} \text { of mixture or } \\
& 425 \pm 33 \mathrm{cal} \mathrm{L}^{-1} \text { at } 25^{\circ} \mathrm{C}, 760 \mathrm{~mm}
\end{aligned}
$$

where $(x)_{\text {LL }}$ is the mole fraction of the fuel vapor in the lower limit mixture and $\Delta_{C}$ is the heat of combustion of the fuel. Obviously, if

$$
(\mathrm{x}) \cdot \Delta_{\mathrm{c}} \approx 10.4
$$

the mixture is flammable while if

$$
\text { (x) } \quad \Delta \mathrm{H}_{\mathrm{C}} \approx 10.4
$$

the fuel-air mixture is below the flammable limit. From Le Chatelier's Law, it follows that for a mixture of fuels at the lower limit

$$
\sum_{i}\left(x_{i}\right) \cdot \Delta H_{c_{i}} \approx 10.4
$$

where $\mathrm{x}_{i}$ is the mole fraction of the $i$ th fuel species, $\Delta \mathrm{H}_{\mathrm{c}_{i}}$ is its heat of combustion, and the sum is taken over all fuel species present. When the sum exceeds 10.4 the mixture is in the flammable range and a flash fire is possible. Thus it is not necessary to know the detailed composition of a complex pyrolyzate mixture or the flammability limits of the individual components in order to estimate its potential to produce a flash fire. It is only necessary to know the total heat of combustion of the pyrolyzate/air mixture.

This minimum energy principle may be further rationalized if we note that the flame temperature of a pre-mixed fuel air mixture is closely related to the heat of combustion of the mixture. The concept of a minimum combustion energy necessary to support a flash fire is then equivalent to a minimum flame temperature necessary to support a stable combustion wave.

A variety of experiments were performed to investigate the applicability of the minimum energy principle to the flash fire problem. 
Four flexible polyurethane foams typical of compositions used in seating construction were selected for detailed study. Two of the foams contained fire retardants while two were unretarded. All were of the TDI poly (propylene oxide) type made with a Sn-amine catalyst. Some of their properties are given in table 7 .

METHODS OF EXPERIMENTAL MEASUREMENT OF THE ENERGY CONTENT OF PYROLYSIS GASES

Several methods of measuring the energy content of the pyrolysis gases were investigated. The method of McCarter [7] has been used extensively in this laboratory to study pyrolysis processes. In this method, the pyrolysis gases, thermally cracked and mixed with air, are carried over a heated catalytic surface. Oxidation of the fuel occurs on the catalyst surface, raising its temperature. The temperature rise gives a measure of the fuel concentration when the instrument is calibrated against known amounts of fuel. The detector's response varies from compound to compound, making it unsuitable for the precise measurement of the energy content of unknown mixtures. Its response to aerosols and particulates is also uncertain. The method is being studied further by Min [8] and a more useful procedure may result. Rather than thermally "crack" the pyrolysis products prior to measurement with the catalytic detector, it was preferred to attempt a direct measurement in another type of detector.

The flame ionization detector, on the other hand, shows a more uniform sensitivity toward organic compounds than the catalytic detector. However, it is insensitive to hydrogen and carbon monoxide and its response to particulates is uncertain. In these studies it was used both as a modification of the McCarter pyrolysis technique and for the analysis of grab samples from the flash fire cell, both with and without partial chromatographite separation of fuel species.

Another possible technique has been described recently by Shafizadeh [9] who measured the oxygen consumed in the combustion of pyrolysis products from cellulose. It is well known that for most organic compounds the energy release per unit mass of oxygen consumed is approximately a constant. This is another manifestation of the minimum energy principle since, for a complex mixture of fuels, the energy available to drive the combustion wave can be characterized more readily by the amount of oxygen consumed than by properties of the fuel. The oxygen consumption method may be useful in further studies of the flash fire problem. 
The most direct method of determining the energy content of the pyrolysis gases appeared to be through the study of samples removed from the flash fire cell. Experiments were carried out on the four polyurethanes described above by the procedure used for the determination of minimum mass. Gas samples were withdrawn from the cell by means of a gas tight syringe immediately before ignition and, in the case of a flash, after ignition. The heat of combustion of the sample was determined by injecting it into a gas chromatograph with flame ionization detectors. The detectors were calibrated with known quantities of methane, so the energy content of the unknown gas mixture could be reported in methane equivalence.

A Varian Aerograph 200 series gas chromatograph with dual flame ionization detectors was used for these measurements. One side of the chromatograph used an unpacked column for the methane equivalent measurements while the other side contained a 6.ft OV-101 packed column. All analyses were run isothermally at $60{ }^{\circ} \mathrm{C}$. The $0 \mathrm{~V}-101$ packed column permitted separation of the lighter fuel components up to about $\mathrm{C}_{5}$ while the empty column passed the entire fuel mixture without separation. The syringe sampling technique undoubtedly removed most of the particulate matter from the sample.

In the case of a flash, the flame speed $\left(\mathrm{S}_{\mathrm{u}}\right)$ was also measured by measuring the times of arrival of the flame front at two thermocouples placed $25 \mathrm{~cm}$ apart. Because of the design of the apparatus, these measurements do not represent true flame speeds, but they do allow useful comparisons to be made. The flame speed for a lean methane-air mixture as measured in the flash fire apparatus was found to be approximately $250 \mathrm{~cm} \mathrm{~s}^{-1}$. The reported flame speed of a lean methane-air mixture lies in the range of $30-37 \mathrm{~s}^{-1}[10]$. The results of these experiments are summarized in tables 8 and 9 . In table 8 , the mass of each sample is tabulated with the oxygen concentration at the time of a flash [02], the maximum temperature reached by the sample $\left(\mathrm{T}_{S}\right)$ and the upward propagation speed of the flame front $\left(\mathrm{S}_{\mathrm{u}}\right)$. Table 9 shows the sample mass, the amount of organic combustible gas content prior to and after a flash in terms of equivalent methane $\left[\mathrm{CH}_{4}\right]$ and the energy content $(\Delta \mathrm{H})$ of these gases prior to a flash.

The samples containing fire retardants (38 and 42) show significantly higher minimum masses than the unretarded samples. The flame speeds appear to fall into two groups, 30 to $60 \mathrm{~cm} \mathrm{~s}^{-1}$ and $>100 \mathrm{~cm} \mathrm{~s}^{-1}$. We can speculate that at the higher flame speeds the fuel vapor concentration was high enough to support the flame while at the lower speeds the volatilization of a significant amount of fuel from the particulates is necessary to provide a flammable mixture. It is known that flame propagation rates in mists and dust clouds are much lower than in homogeneous gas mixtures with similar energy contents [11]. These preliminary experimental results indicate that the flame speed approaches a lower limiting value $\left(30-40 \mathrm{~cm} \mathrm{~s}^{-1}\right)$ as the sample mass approaches its minimum mass. 
This view is supported by the results of the energy content measurements reported in table 9 . In most cases the energy content of the gas, as calculated from the flame ionization data where particulates were presumably eliminated, was below the minimum level necessary to propagate a flame ( $10.4 \mathrm{k}$ cal mole of mixture) even though the original mixture containing particulates flashed in the flash fire cell. The presence of significant fuel concentration in the cell after the passage of the flame front also suggests that additional fuel is vaporizing from particulates not completely consumed in the flash fire.

Further improvements in the accuracy of the measurements will be needed before a more detailed interpretation of these experiments can be made. Reproducibility is a greater problem in these types of experiments than precision. A lack of reproducibility leads to a lower accuracy.

\section{PROBE PYROLYSIS EXPERIMENTS}

In an effort to develop a simpler and more direct method of determining the heat content of the pyrolysis gases, experiments were carried out by pyrolyzing the samples in the inlet port of the gas chromatograph [7, 12]. A pyrolysis probe made by Chemical Data Systems was coupled to the inlet port of a Varian gas chromatograph. The heating rate of the probe could be set between 1 and $5{ }^{\circ} \mathrm{C}$ per second and the probe could be programmed to maintain a pre-selected maximum temperature. A sample of between 0.1 and $0.3 \mathrm{mg}$ of polyurethane was placed in a quartz capillary tube which could be inserted into the platinum wire heating coil of the probe. The samples were heated at a rate of $5{ }^{\circ} \mathrm{C}$ per second to a maximum temperature of $560{ }^{\circ} \mathrm{C}$. The pyrolysis was carried out in a stream of nitrogen. The pyrolysis gases were carried through a heated blank column directly to the flame ionization detector of the chromatograph. Probe temperature and detector output were recorded simultaneously so the output of combustible gases could be observed as a function of temperature. Integration of the detector output and calibration with known quantities of methane provided a measure of the total energy content of the pyrolysis gases. Typical runs are shown in figures $3,4,5$ and 6 . The individual samples are discussed below. The average value and standard deviation of the energy content per unit mass of the pyrolysis products ( $\Delta \mathrm{H}$ pyrolyzate) of each sample is listed in table 10 .

\section{SAMPLE 8}

A pyrolysis run of sample 8 is shown in figure 3. There are two major decompositions. The first occurs in the temperature range $190-370{ }^{\circ} \mathrm{C}$ and the second $330-460{ }^{\circ} \mathrm{C}$. The peak maxima occur at $292^{\circ}$ and $402{ }^{\circ} \mathrm{C}$. The larger peak represents about $70 \%$ of the total amount of combustibles evolved. The shape of the first peak indicates the summation of at least two decomposition reactions and possibly more. The tail after the major decomposition is thought to be due to further decomposition of the residue. The dashed lines represent an attempt to separate the main reactions. 
A pyrolysis run of Sample 16 is shown in figure 4. Again there are two major decompositions with the first decomposition occurring in the temperature range $185-345^{\circ} \mathrm{C}$. The peak maximum occurs near $278{ }^{\circ} \mathrm{C}$. The major decomposition peak, which contributes about $72 \%$ of the total amount of the combustibles evolved, occurs in the temperature range 280-450 ${ }^{\circ} \mathrm{C}$. The peak maximum occurs at $390{ }^{\circ} \mathrm{C}$.

\section{SAMPLE 38}

A pyrolysis run of sample 38 is shown in figure 5. There are again two temperature regions of decompositions. The first which appears to involve several decomposition reactions occurs in the temperature range $150-350{ }^{\circ} \mathrm{C}$ with the peak at about $267^{\circ} \mathrm{C}$. The major peak occurs in the temperature range $290-455{ }^{\circ} \mathrm{C}$ with the peak maximum occurring near $400{ }^{\circ} \mathrm{C}$. The major peak represents about $66 \%$ of the total amount of combustibles evolved.

\section{SAMPLE 42}

A pyrolysis run of sample 42 is shown in figure 6. The two decompositions which occur are similar to the previous sample. The initial peak, which appears to involve several reactions, occurs in the temperature range $160-335{ }^{\circ} \mathrm{C}$ with the peak maximum occurring at $260{ }^{\circ} \mathrm{C}$. The major decomposition reaction occurs in the temperature range $280-455^{\circ} \mathrm{C}$ and the peak maximum occurs at about $388{ }^{\circ} \mathrm{C}$. The major decomposition represents about $65 \%$ of the total amount of combustibles evolved.

The pyrolysis patterns of the fire retarded and unretarded polyurethanes are quite similar. The maximum of the major peak agrees with the previous result [2] that the minimum sample temperature for a flash to occur for polyurethane was $390{ }^{\circ} \mathrm{C}$. The major peak constitutes about $70 \%$ of the total amount of pyrolyzate evolved in each case and the amount of combustibles produced per unit mass is similar, yet the minimum mass of the retarded and unretarded polyurethane samples as determined in the flash fire cell differs by about a factor of two. The flame retardant treatment caused little change in decomposition temperatures or amounts of flammable pyrolyzate. Effective condensed phase flame retardants usually cause a decrease in pyrolysis temperature and reduce the quantity of flammable pyrolysis products. This suggests that the fire retardant is active in the vapor phase.

\section{SUMMARY OF ENERGY CONTENT MEASUREMENTS}

The results of the energy measurements are summarized in table 10 . Heats of combustion $\left(\Delta \mathrm{H}_{\mathrm{C}}\right)$ of the polyurethanes were determined in an oxygen bomb calorimeter. Despite the scatter in the results, it is apparent 
that the pyrolysis probe experiments gave values for the heat of combustion of the pyrolysis products ( $\Delta H$ pyrolyzates) which approximate those of the foam while the flash fire cell experiments give much lower energy values ( $\Delta \mathrm{H}$ flash cell). These results are not unexpected since the pyrolysis experiments were conducted in nitrogen and the pyrolysis products were introduced directly into the detector. Under these conditions, no oxidation would occur prior to introduction of the pyrolyzates into the detector and the only energy loss would be due to the heat of pyrolysis of the sample, incomplete pyrolysis, and possible loss of particulate matter in the short space from probe to detector. In the flash fire cell, on the other hand, the pyrolysis is conducted in air and considerable oxidation may occur in the process. The sampling method also undoubtedly results in extensive loss of particulate matter.

These differences are demonstrated further in table 11 where the available energy per unit volume of pyrolyzate mixture, as determined at the minimum mass level by the various techniques, is compared with the theoretical minimum energy level necessary to support a flash fire (425 $\mathrm{cal} \mathrm{L}^{-1}$ ). The total energy theoretically available from the pyrolysis of the minimum mass of polyurethane is from 2.5 to 5 times as great as that needed to support a flash fire. On the other hand, the measured energy content of the vapor phase in the flash fire cell is somewhat less than the amount needed to support combustion. The difference is due to partial oxidation during pyrolysis and the formation of particulates in the flash fire cell.

The pyrolysis probe experiments could be repeated in air to give an indication of the importance of oxidative processes during pyrolysis. Experiments of the type described here can give a great deal of information on the pyrolysis properties of materials and the flammability of the resulting product mixtures. Further refinements in experimental technique are needed before more detailed conclusions can be drawn.

\section{GAS ANALYSIS EXPERIMENTS}

In an effort to learn more of the details of the pyrolysis process, the light gases produced by the pyrolysis of the unretarded samples 8 and 16 in the flash fire cell were analyzed. Pyrolysis was carried out by the standard procedure. Gas samples were withdrawn from the flash fire cell and analyzed with a Carle AGC 311 gas chromatograph. A 6 ft molecular sieve column and a thermal conductivity detector were used for the light gas analysis. A flame ionization detector was also used for the hydrocarbon analysis. The results are summarized in table 12 .

It is apparent that carbon monoxide (LL 12.5\%) can make a significant contribution to the flash fire potential of sample 8 , particularly when the pyrolysis is carried out at the higher temperatures. Sample 16, on the other hand, produces much less CO. The change in the oxygen/nitrogen ratio is a direct measure of the oxygen consumed during pyrolysis. Oxygen consumption is significant for sample 8, particularly at the 
higher temperature, but appears to be much less for sample 16. Since comsumption of all of the oxygen in the flash fire cell would correspond to an energy release of about $1500 \mathrm{cal}$, comparison with the values in table 11 indicates that oxidative pyrolysis can have a significant effect on the residual energy content of the pyrolysis gases.

\section{SUMMARY AND CONCLUSIONS}

A flash fire cell was developed to provide a method of evaluating the relative flash fire potential of aircraft cabin interior materials. Twenty four typical cabin materials were examined by this method. The method is convenient and provides good discrimination between materials.

In applying the results to the development of safer aircraft interiors, the quantity of material and the likelihood of its being exposed to fire conditions should be considered along with its intrinsic flash fire potential.

A minimum energy principle was proposed to characterize the flash fire behavior of the complex mixture of fuels derived from the pyrolysis of organic materials. This principle states that a flash fire is possible when the potential combustion energy content of the pyrolyzate-air mixture exceeds approximately $425 \mathrm{cal} \mathrm{L}^{-1}$.

A variety of experiments was performed to provide support for the minimum energy principle. The results were in general agreement with predictions, but the accuracy of the measurements was not good enough to permit detailed conclusions.

Oxidative pyrolysis plays a significant role in the formation of the fuel-air mixture in the flash fire cell. Particulates contribute to the creation of flash fire conditions, but they present a difficult measurement problem. 


\section{REFERENCES}

[1] Paabo, M. and Comeford, J. J., A Study of the Decomposition Products of Polyurethane Foam Related to Aircraft Cabin Flash Fires, National Bureau of Standards (U.S.) Report No. FAA-RD-73-46 (1973).

[2] Brown, J. E. and Comeford, J. J., Technique for the Measurement of Flash Fire Potential of Polymeric Materials, National Bureau of Standards (U.S.) Internal Report No. 75-757 (1975).

[3] Pagni, P. J. and Shih, T-M., Excess Pyrolyzate, 16th Symposium (Internationa1) on Combustion, 1976.

[4] Hertzberg, M., The Theory of Flammability Limits, Bureau of Mines Report of Investigations 8127 (1976).

[5] Zabetakis, M. G., Flammability Characteristics of Combustible Gases and Vapors, Bureau of Mines Bulletin 627 (1965).

[6] Kuchta, J. M., Fire and Explosion Manual for Aircraft Accident Investigators, Technical Report No. 4193, Bureau of Mines, Pittsburgh, Pa. (1973).

[7] McCarter, R. J., J.Appl. Poly. Sci., 171833 (1973).

[8] Min, K., Dynamics of Pyrolysis of Cellulosis Materials, Paper presented at the Central States Meeting of the Combustion Institute, San Antonio, 1975.

[9] Shafizadeh, F., University of Montana. Private communication, to be published.

[10] Coward, H. F. and Jones, G. W., Limits of Flammability of Gases and Vapors, U. S. Bureau of Mines Bulletin No. 503 (1952).

[11] Burgoyne, J. H., The Flammability of Mists and Sprays, Second Symposium on Chemical Process Hazards, p. 1 (1963).

[12] Eggertsen, F. T. and Stross, F. H., Thermochim. Acta, 1, 451 (1970).

[13] McCarter, R. J., J. Cons. Prod. Flam., 3, 128 (1976). 
Table 1. Materials Evaluated in Flash Fire Cell

Sample No.

1

2

$6 \mathrm{~A}$

10

14
Material Description

Tedlar finish, epoxy-fiberglass faces Nomex honeycomb core

Epoxy-fiberglass faces, Nomex honeycomb core

Tedlar finish, PRD-49 Kevlar-phenolic finish

Polyester-fiberglass sheet

Perforated Tedlar finish, Nomex paper-epoxy front face, Nomex honeycomb core, fiberglass-epoxy back face

Epoxy-fiberglass sheet

Fiberglass batting, melamine binder

Molded Lexan polycarbonate

Wool pile, polyester backing and FR latex back coating

Wool pile face, polyester backing, FR latex back coating, urethane foam pad and nylon scrim

Tedlar finish, fiberglass screen, Nomex honeycomb core filled with fiberglass batting, phenolic/epoxy-fiberglass back face

Wool carpet finish, phenolic/epoxyfiberglass front face, epoxy adhesive, Nomex honeycomb, epoxy-fiberglass back face

Tedlar/PVC finish, phenolic-fiberglass front face, epoxy adhesive, Nomex honeycomb core, phenolic-fiberglass back face

Silicone treated, phenolic impregnated fiberglass batt
Usage

Ceiling panel

Ceiling panel

Window reveals and sidewalls

Cargo liner

Wall panel

Cargo liner

Cabin insulation

Access cover

Carpet

Carpet

Center ceiling panel

Lower sidewa 11 panel

Overhead stowage panel

Cabin insulation 
Sample No.

67

78

86

88

111

$115 \mathrm{~A}$

117

130

$143 \mathrm{~A}$

$143 \mathrm{C}$
Material Description

PVC finish, phenolic/epoxy-fiberglass front face, epoxy adhesive, Nomex honeycomb core, epoxy-fiberglass back face

Nomex fabric

PVC foam

FR wool fabric

Lexan polycarbonate sheet

Phenolic impregnated fiberglass batt

Noryl poly (phenylene oxide) thermoforming material

FR coating, cotton/rayon fabric

Polyester urethane foam

Polyester urethane foam
Usage

Door liner

Attendant seat cover

Flotation, seat back and arm rest padding

Crew seat cover

Transparency

Cabin insulation

Passenger service unit

Attendant seat cover

Seat cushion

Seat cushion 
Table 2. Flash Fire Test Results

\begin{tabular}{cccc} 
Sample & Min. Mass, ${ }^{\mathrm{a}} \mathrm{gL}^{-1}$ & $\mathrm{~T}_{\text {sample, }}^{\mathrm{b}}{ }^{\circ} \mathrm{C}$ & \\
\hline 1 & & & \\
2 & 2.77 & $420-480$ & $12-14$ \\
2 & 2.91 & $430-480$ & $17-19$ \\
$6 \mathrm{~A}$ & 1.41 & $460-470$ & $16-17$ \\
10 & 0.84 & $400-440$ & $19-20$ \\
14 & 4.30 & $480-500$ & $18-19$ \\
26 & $>2.04$ & $430-500$ & $14-16$ \\
27 & $>1.83$ & 500 & 17.5 \\
32 & 1.20 & $470-500$ & $18-19$ \\
33 & 0.55 & $440-480$ & $18-19$ \\
34 & 0.55 & $430-470$ & $16-18$ \\
37 & $>2.35$ & $480-500$ & $15-17$ \\
50 & $>1.70$ & $475-495$ & $14-15$ \\
61 & $<3.30$ & $480-500$ & $16-18$ \\
66 & $>2.35$ & 500 & 19 \\
67 & $>3.67$ & $460-470$ & $15-17$ \\
78 & $>2.09$ & $480-500$ & 16 \\
86 & 0.67 & $500-540$ & $15-18$ \\
88 & 0.62 & $420-460$ & $17-18$ \\
111 & 1.25 & 500 & $18-19$ \\
$115 \mathrm{~A}$ & $>2.35$ & 500 & 18 \\
117 & 0.23 & $450-480$ & $19-20$ \\
130 & $>1.37$ & 460 & 10 \\
$143 \mathrm{~A}$ & 0.41 & $430-500$ & $15-19$ \\
$143 \mathrm{C}$ & 0.72 & $420-500$ & $17-19$
\end{tabular}

a Minimum mass for samples which flashed; largest sample tested for those which did not flash.

b Maximum temperature reached by sample at time of flash or maximum temperature reached in case of samples which did not flash.

c Oxygen concentration at time of flash or minimum concentration reached in case where samples did not flash.

d Sample flashed. Shortage of material prevented testing smaller samples.

e Oven temperature $600{ }^{\circ} \mathrm{C}$. 


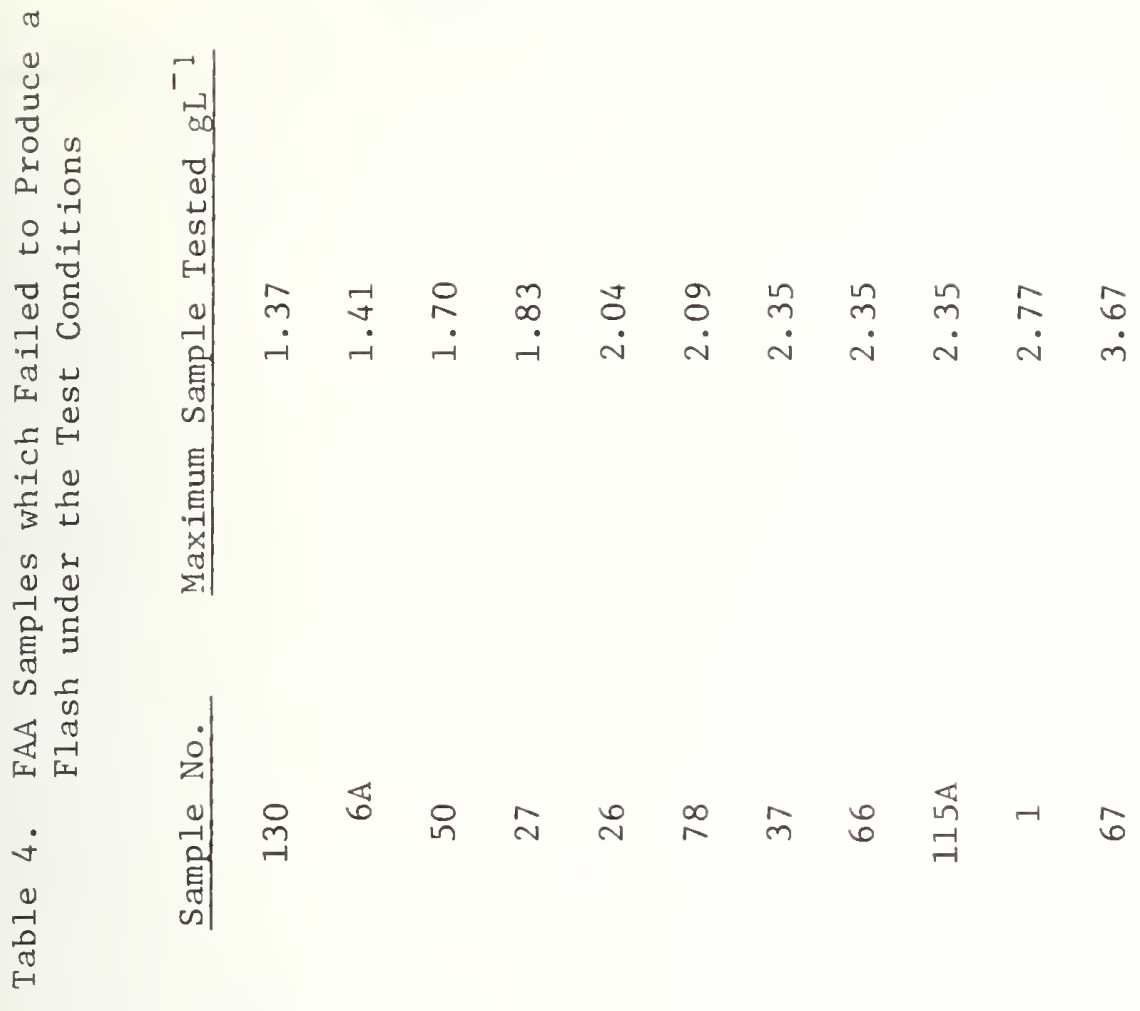

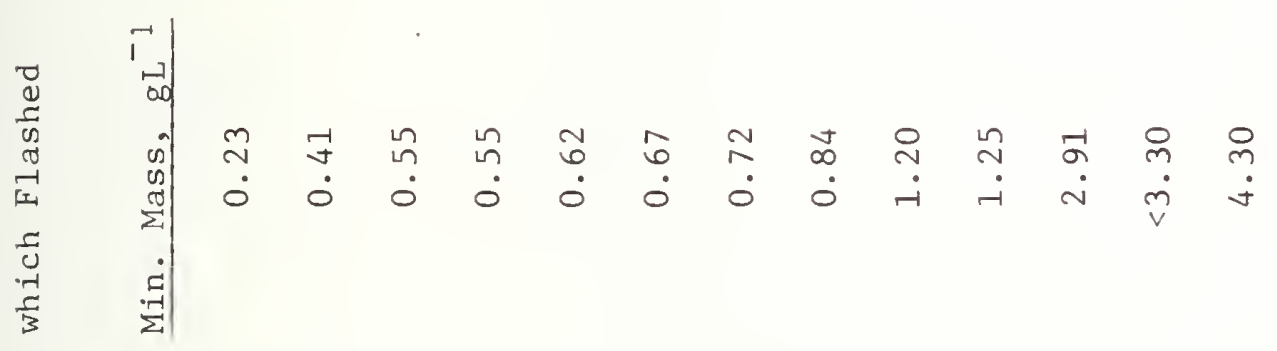

岂

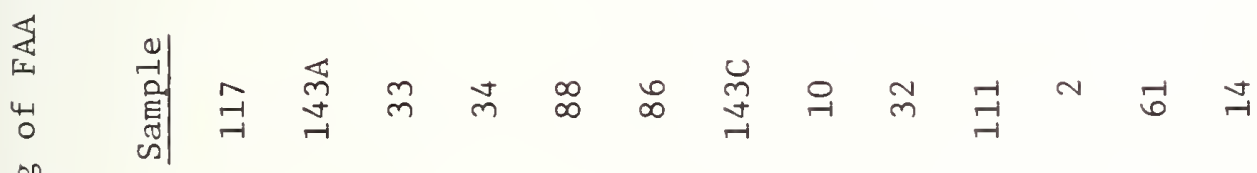

苞

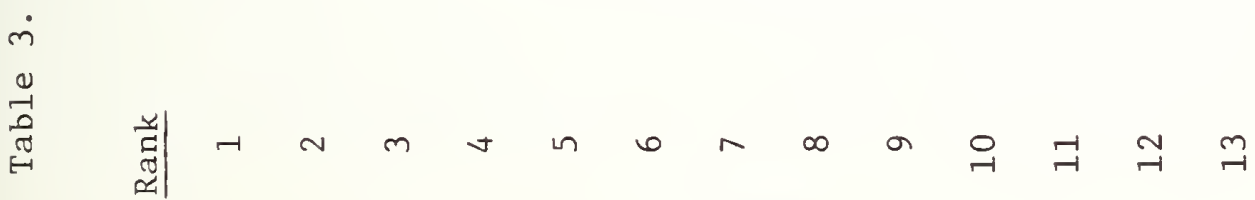


Table 5. Results of Composite Samples

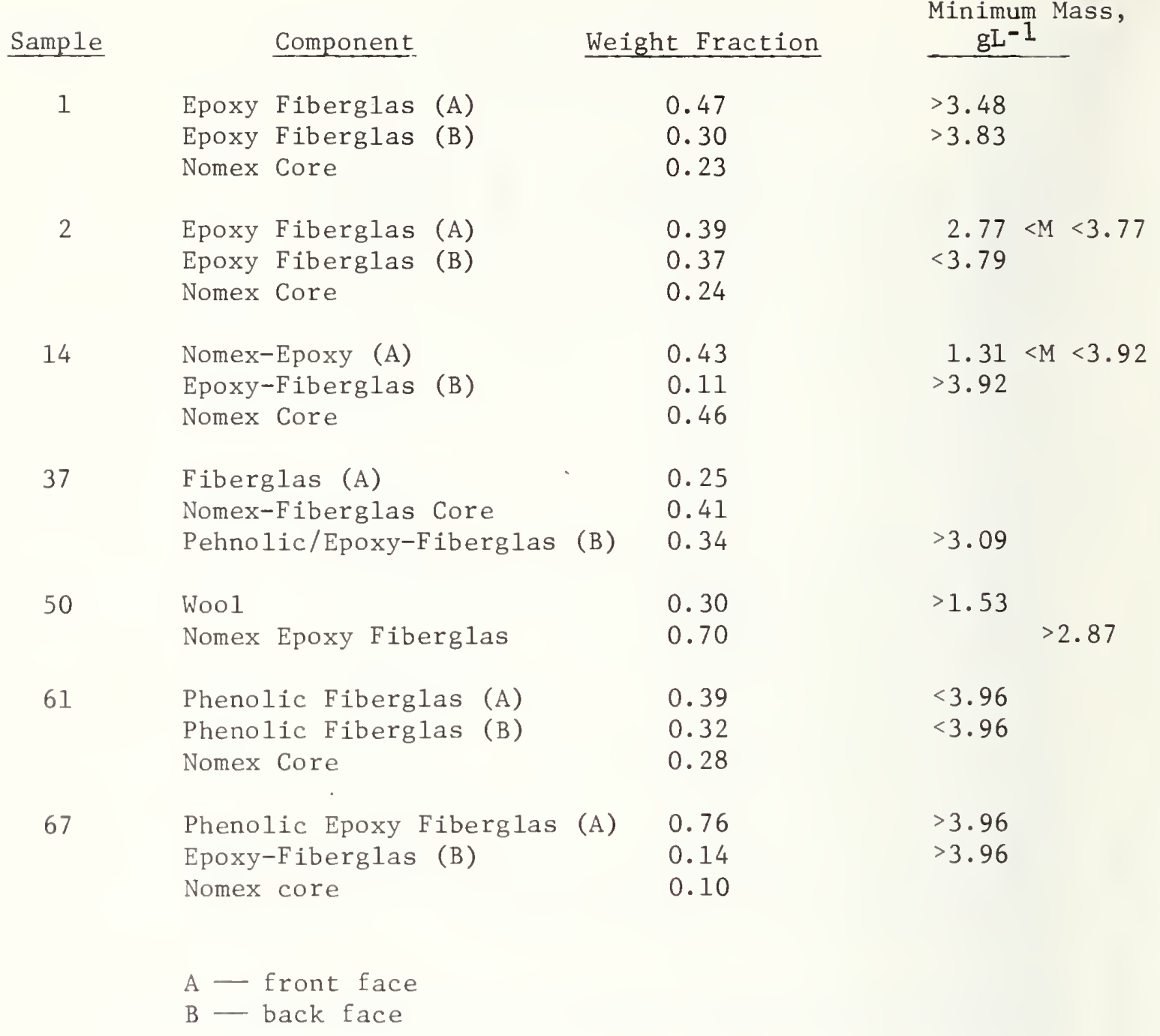


Table 6. Lean Limit Mixture Heats of Combustion for Upward Flame Propagation of Organic Fuels

\begin{tabular}{|c|c|c|c|}
\hline Fuel & ${ }^{(x)}{ }_{L L}$, Vol. $\%$ & $\Delta \mathrm{H}_{\mathrm{c}}, \mathrm{kcal} \cdot \mathrm{mole}^{-1}$ & ${ }^{(\mathrm{x})} \frac{\mathrm{LL}}{100} \cdot \Delta \mathrm{H}_{\mathrm{C}}$ \\
\hline Methane & 5.00 & 191.76 & 9.6 \\
\hline Ethane & 2.95 & 341.26 & 10.1 \\
\hline Propane & 2.12 & 488.53 & 10.4 \\
\hline n-Pentane & 1.41 & 782.04 & 10.9 \\
\hline cyclo-Hexane & 1.3 & 908 & 11.8 \\
\hline Propylene & 2.0 & 460.4 & 9.2 \\
\hline Benzene & 1.3 & 757.5 & 9.8 \\
\hline Toluene & 1.2 & 901.5 & 10.8 \\
\hline Pyridine & 1.8 & 633 & 11.4 \\
\hline Ethanol & 3.3 & 306 & 10.1 \\
\hline Ethylene glycol & 3.2 & 311 & 10.0 \\
\hline Methyl ether & 3.4 & 316 & 10.7 \\
\hline Acetone & 2.6 & 403 & 10.5 \\
\hline Acetaldehyde & 4.0 & 264 & 10.6 \\
\hline Ethyl acetate & 2.2 & 504 & 11.1 \\
\hline
\end{tabular}

Average $x \quad 10.4 \pm 0.8$

Data taken from reference 6 .

Table 7. Properties of Polyurethane Foam Samples

(c)

\begin{tabular}{crccc}
$\begin{array}{c}\text { Sample } \\
\text { No. }\end{array}$ & Polyol & $\begin{array}{c}\text { Flame } \\
\text { Retardant }\end{array}$ & $\begin{array}{c}\text { Density } \\
\mathrm{kg} / \mathrm{m}^{3}\end{array}$ & $\begin{array}{c}\text { Oxygen } \\
\text { Index }\end{array}$ \\
\hline 8 & ungrafted & none & 29 & $151 / 2$ \\
16 & grafted & none & 40 & $201 / 2$ \\
38 & ungrafted & Br,P & 35 & 21 \\
42 & grafted & Br, P & 72 & 29 \\
\hline
\end{tabular}

(a) Polyacrylonitrile grafted to the polyol

(b) per ASTM D 2863-70

(c) Data from reference 13 
Table 8. Results of Flash Fire Experiments for Samples $8,16,38 \& 42$

\begin{tabular}{|c|c|c|c|c|c|c|}
\hline Sample & $\begin{array}{c}\text { Mass, } \\
\text { g }\end{array}$ & $\begin{array}{l}{\left[\mathrm{O}_{2}\right],{ }^{\mathrm{a}}} \\
\text { vol. } \%\end{array}$ & ${ }^{\mathrm{T}_{\mathrm{S}},}{ }_{\mathrm{C}}$ & Flash? & $\mathrm{cm}$ & $\begin{array}{l}\mathrm{S}_{\mathrm{u}},-1 \\
\mathrm{sec}^{-1}\end{array}$ \\
\hline \multirow[t]{7}{*}{8} & 0.4228 & 18.7 & 467 & YES & & 125 \\
\hline & 0.3801 & 18.6 & 500 & YES & & 56 \\
\hline & 0.3415 & 18.3 & 483 & YES & & 143 \\
\hline & 0.3410 & 18.7 & 466 & YES & & 30 \\
\hline & 0.3383 & 17.1 & 452 & YES & & 222 \\
\hline & 0.3240 & 19.0 & 500 & YES & & 37 \\
\hline & 0.3045 & 15.7 & 468 & NO & & -- \\
\hline \multirow[t]{6}{*}{16} & 0.4813 & 16.7 & 393 & YES & & 42 \\
\hline & 0.4151 & 15.1 & 438 & YES & & 167 \\
\hline & 0.4130 & 14.6 & 435 & YES & & 56 \\
\hline & 0.4030 & 16.9 & 359 & YES & & 36 \\
\hline & 0.3664 & 15.6 & 345 & NO & & -- \\
\hline & 0.3052 & 15.7 & 345 & NO & & - \\
\hline \multirow[t]{5}{*}{38} & 0.6827 & 17.2 & 427 & YES & & 31 \\
\hline & 0.6611 & 17.6 & 433 & YES & & \\
\hline & 0.6570 & 17.3 & 399 & YES & & 34 \\
\hline & 0.6454 & 16.2 & 427 & NO & & -- \\
\hline & 0.6308 & 14.2 & 374 & NO & & -- \\
\hline \multirow[t]{10}{*}{42} & 0.6780 & 16.6 & 445 & YES & & \\
\hline & 0.6712 & 16.2 & 445 & YES & & 36 \\
\hline & 0.6488 & 17.4 & 433 & NO & & -- \\
\hline & 0.6270 & 16.6 & 414 & No & & -- \\
\hline & 0.6209 & 15.9 & 362 & YES & & 42 \\
\hline & 0.6033 & 13.7 & 386 & NO & & -- \\
\hline & 0.5795 & 16.3 & 340 & NO & & -- \\
\hline & 0.5363 & 15.1 & 360 & NO & & - \\
\hline & 0.5026 & 14.9 & 354 & NO & & -- \\
\hline & 0.4375 & 16.2 & 377 & NO & & -- \\
\hline
\end{tabular}

a oxygen concentration at flash or minimum oxygen concentration reached in case where sample did not flash.

$\mathrm{b}$

Maximum temperature reached by sample. 
Table 9. Results of Energy Measurements of Flash Fire Experiments for Samples 8, 16, 38 and 42

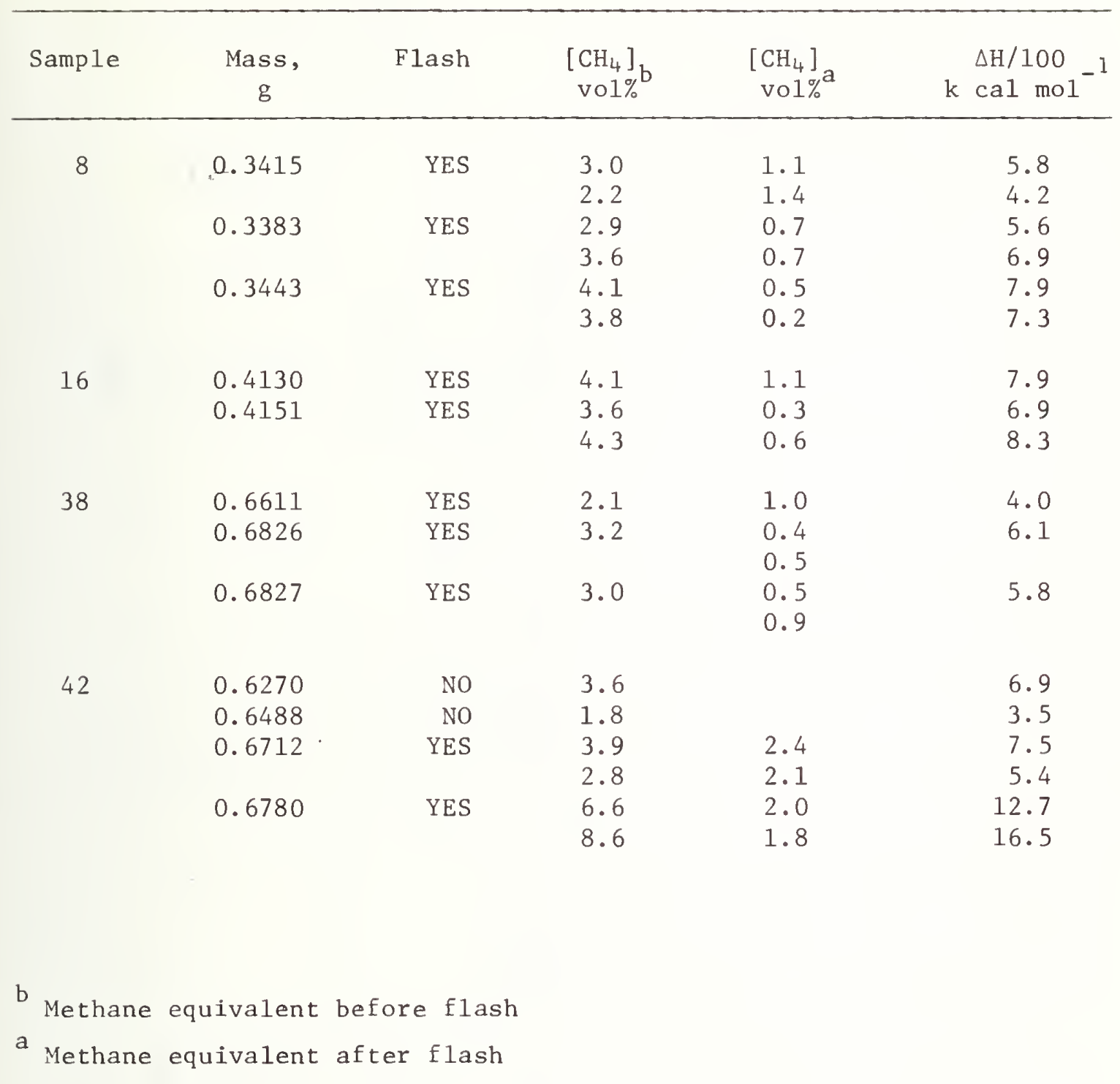




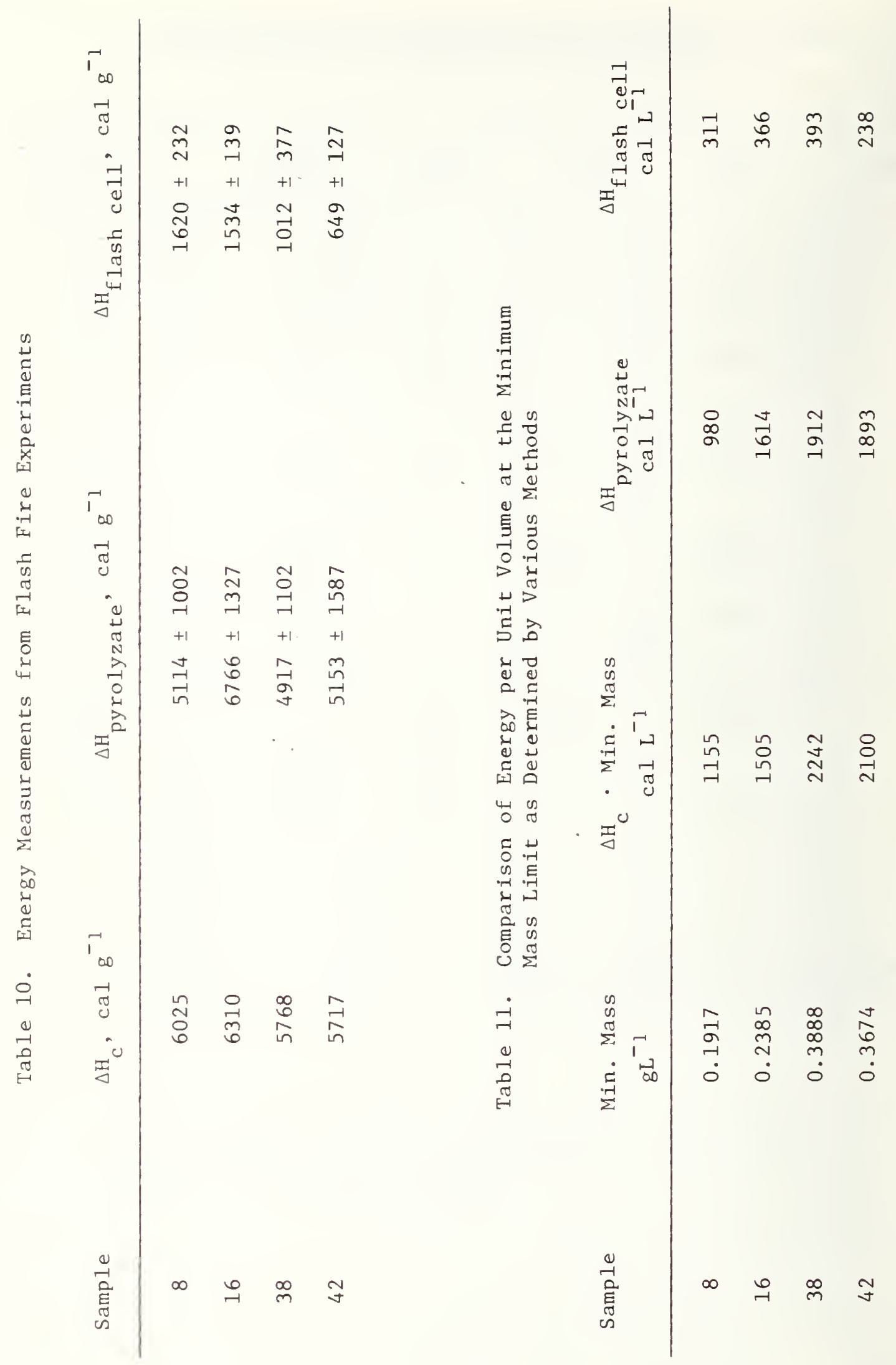




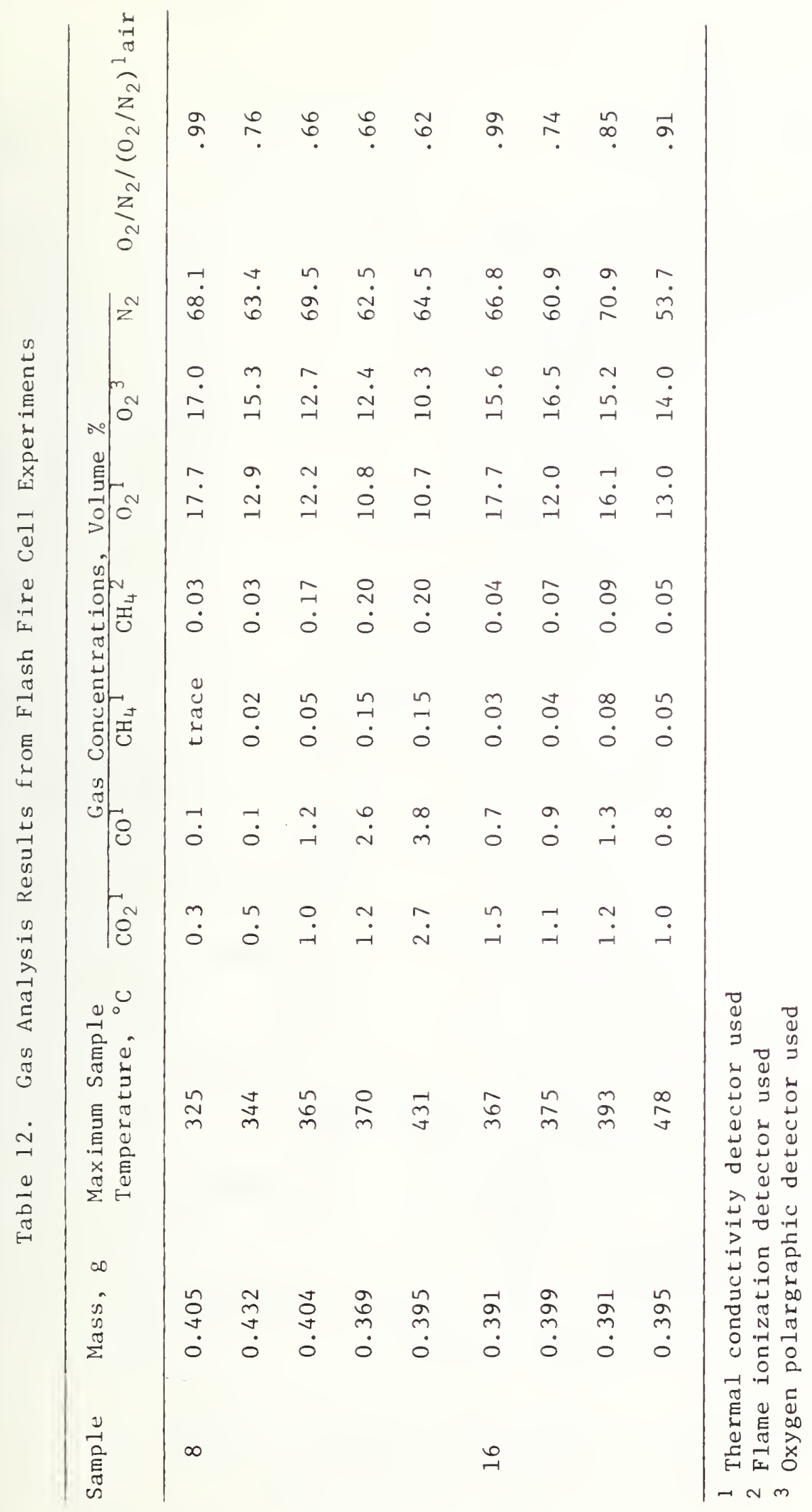




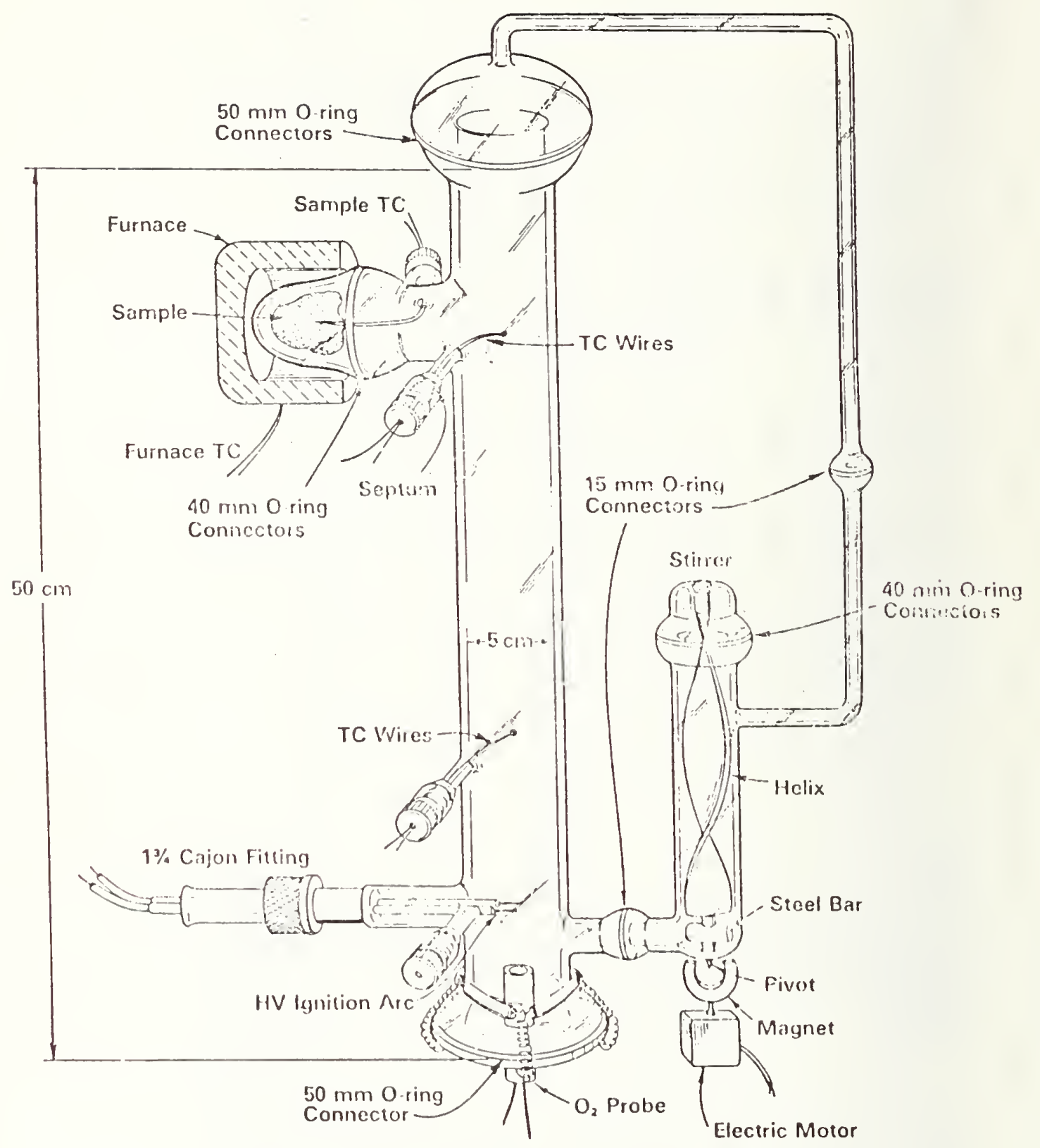

FIGURE 1. MODIFIED FLASH FIRE CELL 

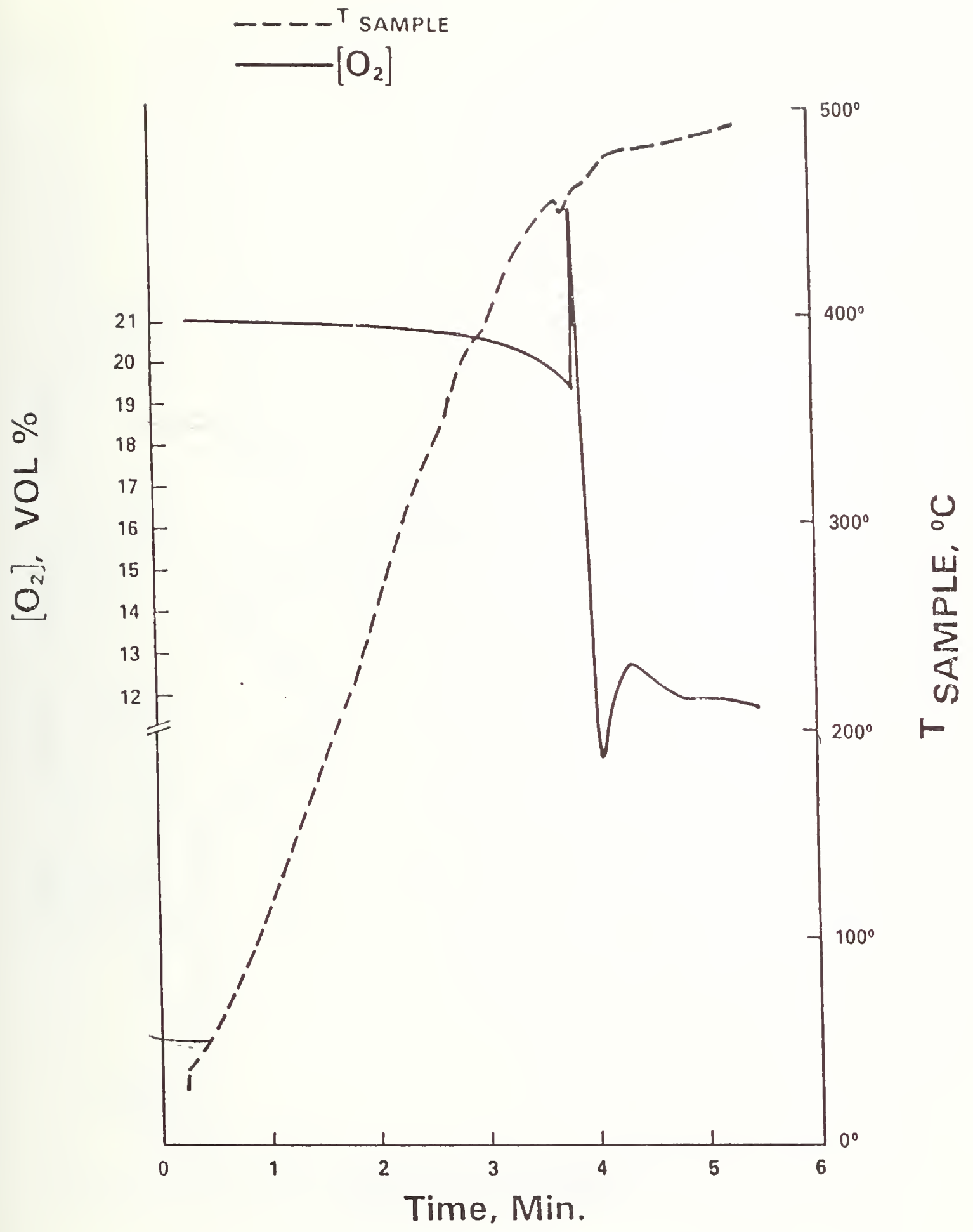

FIGURE 2. TYPICAL EXPERIMENTAL RUN WHERE SAMPLE PYROLYZATES PRODUCE A FLASH FIRE 


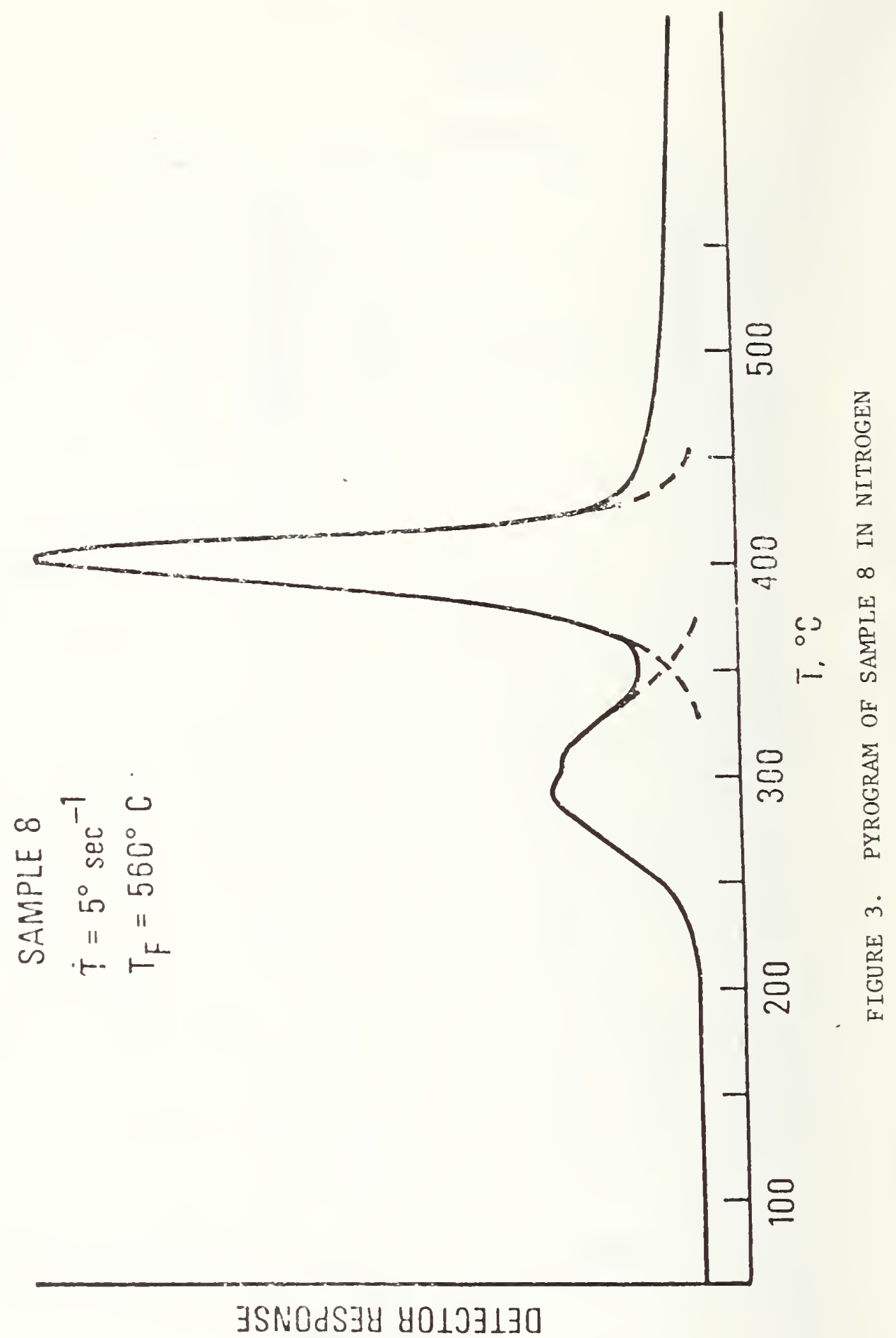




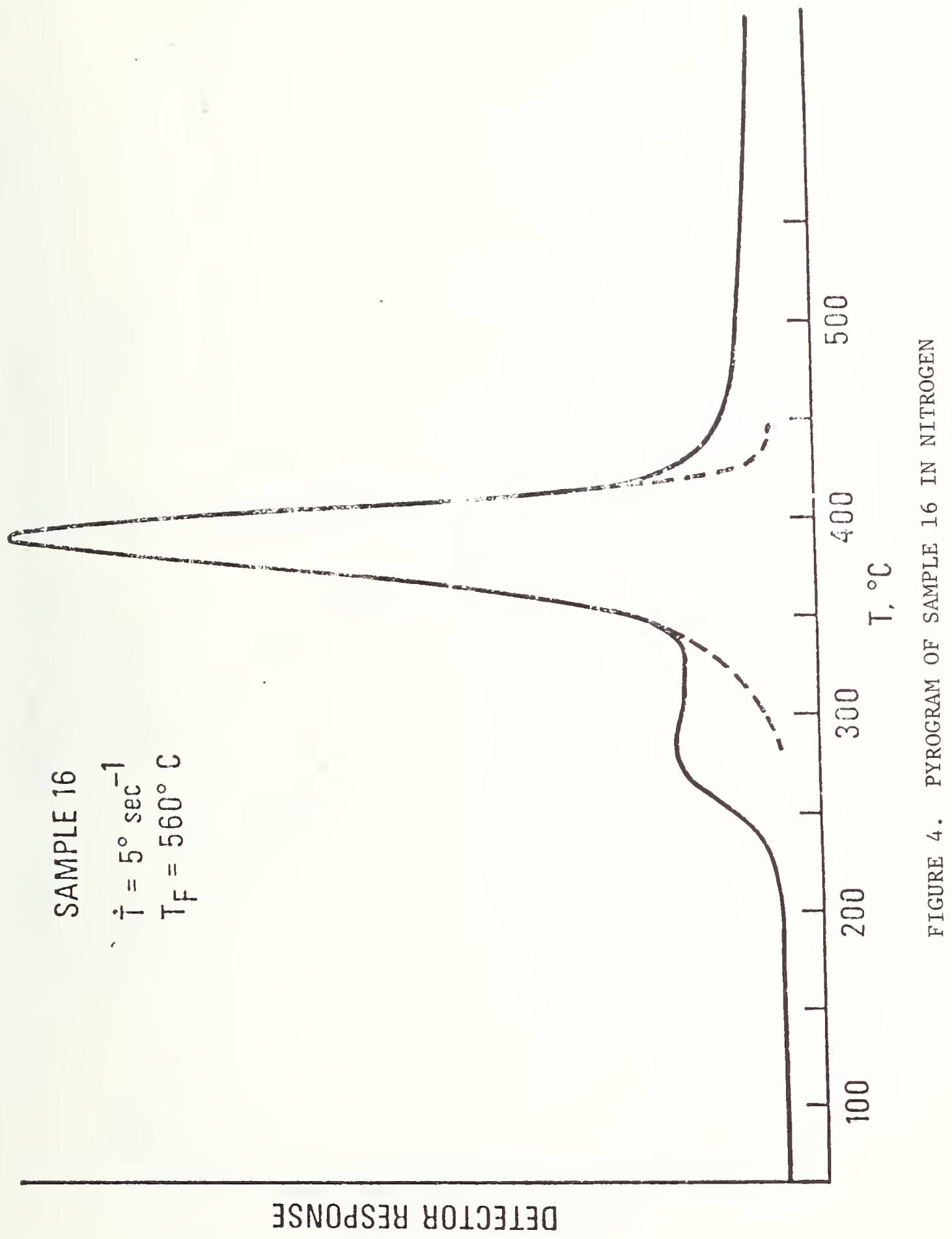




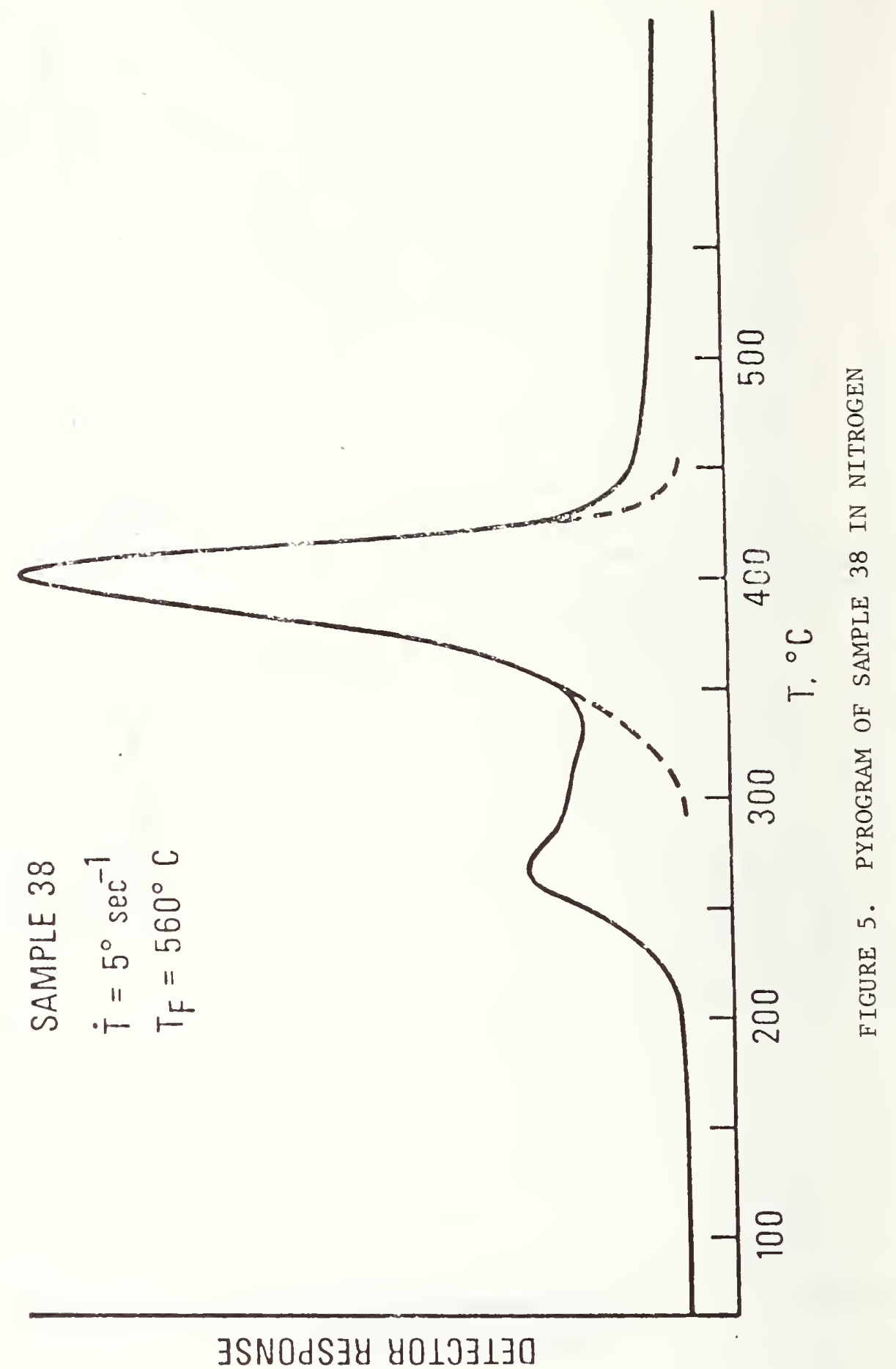




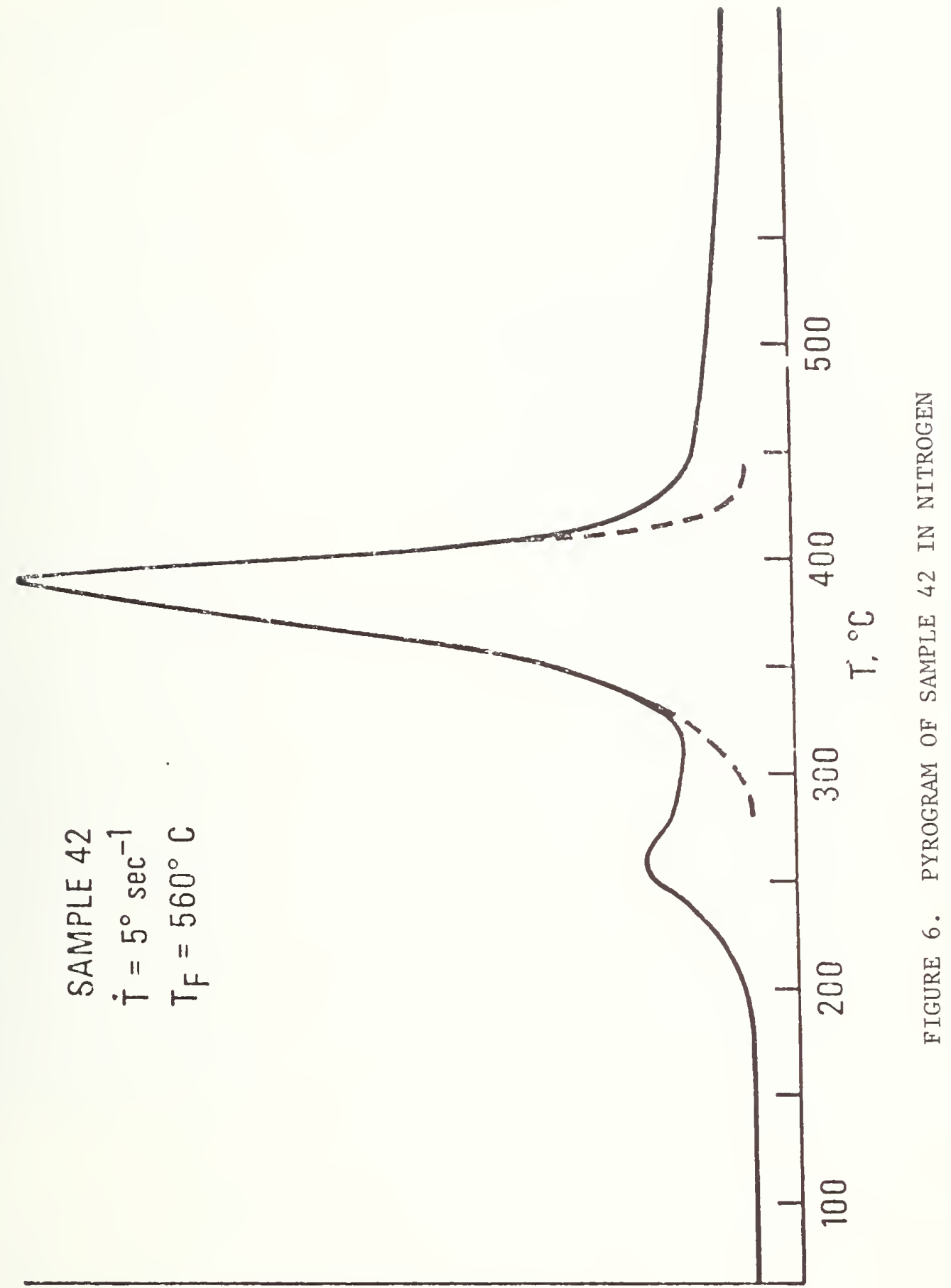

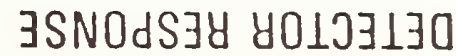


